\title{
Anchoring Democracy from Above? The European Union and Democratic Backsliding in Hungary and Romania after Accession
}

\section{ULRICH SEDELMEIER}

London School of Economics and Political Science

forthcoming in Journal of Common Market Studies, Vol. 52, Issue 1 (January 2014)

\section{Introduction $^{1}$}

The contribution of the European Union (EU) to democratization in post-communist Europe was particularly important in countries that experienced domestic contestation between liberal-democratic parties and authoritarian and/or nationalist parties (see e.g. Schimmelfennig, 2005; Vachudova, 2005). After elections brought liberal-democratic parties to power, the conditional incentive of membership locked in democratic practices even when former illiberal parties subsequently returned to power. But can the EU continue to anchor democracy after a country has obtained membership?

The incentive structure for governments that expect strategic advantages through undemocratic practices changes after accession (Epstein and Sedelmeier, 2008, p.798; Schimmelfennig and Sedelmeier, 2004, p.676). The sanctions available to EU institutions are much weaker than the threat of withholding membership during the pre-accession phase. Moreover, the autonomy of EU institutions to sanction breaches of liberal democratic principles is more limited than in areas of EU law where the

\footnotetext{
${ }^{1}$ For helpful comments, I am grateful to Sabina Avdagic, Tanja Börzel, Rachel Epstein, Wade Jacoby, Milada Vachudova, and two anonymous referees.
} 
Commission can initiate infringement procedures and the European Court of Justice (ECJ) can impose financial penalties (Sedelmeier, 2008). Yet despite the danger of backsliding that the changing incentive structure after accession evokes, studies initially suggested that the EU's new member states have experienced at best a slow down, rather than a reversal, of pre-accession democratic and good governance reforms (Levitz and Pop-Eleches, 2010; Pridham, 2008; Sedelmeier, 2012; Spendzharova and Vachudova, 2012).

However, political developments in Hungary and Romania since 2012 challenge these rather positive findings. In Hungary, the centre-right Alliance of Young Democrats (Fidesz) won 52.7 percent of the vote in the 2010 parliamentary election, giving it a two-third majority in parliament. This supermajority has enabled Prime Minister (PM) Viktor Orban's government to pass a new constitution - criticized by the Council of Europe's Venice Commission in June 2011 - and numerous statutes. Without formally violating the rule of law, they contravene basic principles of liberal democratic competition and fundamental freedoms (see e.g. Bánkuti, et al., 2012; Scheppele, 2013). The government has concentrated and entrenched its power. It weakened notably the constitutional court, seized control of key public institutions (by packing them with party loyalists and extending mandates much beyond the term of parliament), changed the electoral law, and requires two-thirds majorities to change some of its policies. In Romania, a re-alignment of party alliances in May 2012 led to a parliamentary majority for PM Victor Ponta's centre-left Social-Liberal Union (USL). In July, the new government suspended the centre-right president, Traian Băsescu. Through emergency ordinances it removed constitutional checks on the impeachment procedure, including a weakening of the constitutional court and a 
lifting of the 50 percent participation quorum for the referendum required to validate the impeachment (see e.g. Pop-Eleches, 2013). The Venice Commission criticized these practices in December 2012.

This article analyzes to what extent the EU has been able to redress the breaches of liberal democratic principles in Hungary and Romania in order to understand more generally the scope and limits of the EU's ability to lock-in democratic practices after a state has obtained membership. The question of how effectively the EU used the instruments at its disposal requires answering two separate questions. First, why did the EU forego the use of its most powerful instrument explicitly designed to sanction breaches of democratic principles in the member states? Second, how can we explain variation in the success of the instruments the EU actually used?

Regarding the first question, what is striking about the EU's choice of instruments to redress democratic backsliding in Hungary and Romania is that it did not use its most powerful instrument, namely the sanctions and monitoring of Article 7 TEU that allows the member states to withdraw certain membership rights - including voting in the Council - for serious and persistent breaches of democratic principles. While the fairly rapid agreement of the Romanian PM to the EU's demands made sanctions unnecessary, the non-use against Hungary requires an explanation. Even if we take account of the demanding majority requirements to use Article 7 and consider that member states would be generally reluctant to use this nuclear option, why did they not even agree to use the preventive monitoring mechanism of Article 7? Similarly, if we assume that actors are generally reluctant to use Article 7, why did some governments and party groups in the European Parliament (EP) advocate its use? The 
article's first question is thus how we can understand the variation of actor preferences for and against the use of Article 7 and the implications for its use in possible future cases.

To explain these preferences, this article identifies four hypotheses that advance different expectations about which actor characteristics and context conditions predispose actors to support or oppose the use of Article 7. Constructivism suggests that these preferences vary depending on the extent of actors' commitment to liberal democracy, and/or their attitudes towards supranational integration. Rationalist institutionalism focuses on actors' strategic use of sanctions to weaken illiberal domestic rivals and/or strengthen partisan allies abroad. The article finds that a combination of actors' commitment to liberal democracy and transnational partisan politics best explains actors' preferences regarding the use of Article 7: actors opposed Article 7's use if they had a weaker normative commitment to liberal democracy and when the targets of these sanctions were partisan allies abroad. Conversely, support for sanctions came both from actors with a strong commitment to liberal democracy (regardless of the targets' partisan orientation) or from actors with a weaker commitment to liberal democracy if the sanctions targeted partisan rivals.

Yet despite the EU's inability to mobilize its strongest instrument, EU institutions had some qualified success in using other instruments to press for changes in contentious legislation and practices. Especially in the case of Romania, PM Ponta largely complied with EU demands. The second question of the article thus concerns the effectiveness of the various instruments that the EU used across countries and issues. 
Why was the EU better at stopping backsliding in Romania than in Hungary? And how can we explain differences across issue areas in Hungary?

To answer these questions, the article contrasts rationalist institutionalist and constructivist explanations that attribute variation in the EU's success respectively to differences in its material leverage and to the presence of factors conducive to the use of social pressure. The analysis suggests that the EU is not necessarily powerless against democratic backsliding. The size of material threats that the EU can make through infringement procedures and issue-linkage matter, but the range of issues and countries to which they can be applied is limited. The Romanian case suggests that governments are susceptible to social pressure if the conditions are favourable. But even then, social pressure might need to be applied in the shadow of material sanctions through issue linkage in order for the target government to redress breaches of democratic practice.

\section{The Article 7 sanctioning mechanism against breaches of democracy}

The EU's main instruments against general breaches of democratic principles are contained in Article 7. Although the member states also had concerns in the Mediterranean enlargements of the 1980s that post-authoritarian new member states might be susceptible to set-backs after accession (Wallace, 1996), they only created the possibility of sanctions in the context of the eastern enlargement (Sadurski, 2012, pp.81-4). The Treaty of Amsterdam of 1997 established a sanctioning mechanism for infringements of the values referred to in Article 2 - 'respect for human dignity, freedom, democracy, equality, the rule of law and respect for human rights, including 
the rights of persons belonging to minorities' as well as 'pluralism, nondiscrimination, tolerance, justice, solidarity and equality between women and men'. If the EU establishes that there is a 'serious and persistent breach' of these values by a member state, the Council can agree by qualified majority to suspend certain treaty rights of that state, including its voting rights. However, the determination of such a breach is very demanding. It requires a proposal by either one third of the member states or the Commission, the consent of the EP (by a $2 / 3$ majority of votes cast if representing a majority of MEPs) and unanimous agreement in the European Council (not counting abstentions or the member state accused). The Treaty of Nice added a preventive procedure (with less demanding majority requirements) to determine the existence of 'a clear risk' of a serious breach of liberal democratic principles. It can be proposed by either one third of the member states, the Commission, or the EP and requires the consent of the EP and a four-firth majority in the Council (minus abstentions and the member state concerned).

By 2012, the EU had never used Article 7. The closest it came to sanctioning a member state was in 2000 when the centre-right Austrian People's Party formed a coalition government with the populist radical-right Freedom Party (FPÖ). It is important to note that the sanctions used in this case were not EU measures - let alone based on Article 7 (as is occasionally wrongly suggested, see e.g. EUobserver, 06.07.2012). Instead, the other member states adopted bilateral, albeit coordinated diplomatic sanctions against the Austrian government. Another peculiarity of this case was that the concerns did not focus on an actual breach of the EU's fundamental values, but on their incompatibility with those of the FPÖ and its leader, Jörg Haider. The dissatisfaction with how the Austrian case was handled and the limitations of the 
treaty framework for dealing with such a case led to the inclusion of the preventive mechanism to establish the risk of a serious breach in the Treaty of Nice.

The cases of Hungary and Romania in 2012 are more clear-cut for the use of Article 7. The rapid acquiescence of the Romanian government to the EU's demands can explain why the EU did not need to use Article 7 there, but why did it not do so against Hungary? Maybe the very demanding majority requirements make this outcome appear not particularly surprising. At the same time, given the member states' willingness to sanction the Austrian government in 2000 on much weaker grounds, it seems striking that the EU could not even muster the less demanding majority to determine a 'risk' of a serious breach in Hungary. Moreover, even if we generally consider governments to be highly reluctant to use this 'nuclear option', some governments and EP groups did advocate the use of Article 7. How we can account for such variation in actors' preferences? A better understanding of these preferences is instructive for a more general explanation of the EU's ability to use sanctions in other cases of democratic backsliding that might arise.

\section{Theoretical framework to explain actor preferences towards the use of sanctions}

Drawing on the debate between rationalist institutionalism and constructivism, we can derive from each approach two main propositions about the context and characteristics of actors that incline them either to oppose or support sanctions against member states that breach liberal democratic principles. Despite the obvious differences, the case of sanctions against Austria in 2000 is instructive for analysing 
actors' preferences across member states and EP party groups concerning the use of Article 7 more generally. It suggests that rationalism and constructivism not only provide competing but also potentially complementary explanations for the support and opposition to sanctions (Merlingen, et al., 2001).

Rationalist institutionalism: domestic and international partisan politics

A rationalist perspective suggests two different types of partisan motives for actors to support or oppose the use of Article 7. The first focuses on the instrumental use of EU measures to constrain domestic partisan opponents (for such an argument for the creation of the ECHR, see Moravcsik, 2000). In the Austrian case of 2000, (intraparty) partisan politics explain why certain governments took the lead in mobilizing support for sanctions (Merlingen, et al., 2001, pp.67-70). In France and Belgium, EUlevel measures to punish cooperation between centre-right and extreme right parties strengthened the positions of Jacques Chirac and Guy Verhofstad against intra-party rivals who were open to cooperation with the extreme right.

If the issue at stake is not cooperation with extremist parties, but violations of democratic practices by the government, ${ }^{2}$ parties that face illiberal domestic competitors have incentives to use international sanctions against violators of democratic practices elsewhere. These governments might fear that their rivals would use undemocratic practices to obtain or preserve power and can be expected to support EU-level sanctions to counter this threat. The domestic partisan politics

\footnotetext{
${ }^{2}$ The Austrian case has less similarity with Hungary and Romania in 2012 than with Slovakia in 2006 when the social democratic Smer-SD formed a coalition government with the extreme-nationalist Slovak National Party, leading to the expulsion of Smer-SD from the EP's S\&D party group.
} 
hypothesis thus suggests that a member state government supports sanctions if the opposition parties' normative commitment to liberal democratic values is weak.

The second type of partisan incentives relates to the left-right cleavage in party politics. Parties are likely to advocate international sanctions against their ideological adversaries in other member states and to be more permissive of democratic backsliding within their own party family. In this case, the incentives are not from domestic political competition. Supporting like-minded parties abroad increases the likelihood of achieving international cooperation close to a government's ideological position. The international partisan politics hypothesis is therefore that a member state government (EP political group) supports sanctions if it is ideologically distant from the government party of the target state.

Constructivism: normative commitment to democracy and to supranational governance

Constructivism draws attention to two characteristics of actors that can explain their support or opposition to sanctions: actors' normative commitment to liberal democracy and supranational integration respectively. With regard to the former, actors can be expected to support sanctions if they have a strong normative commitment to upholding liberal democratic principles. A strong normative consensus should lead to an agreement to use the full force of available instruments against deficiencies within the EU. At the same time, variation in the strength of this commitment across actors can be expected to lead to divergent preferences regarding the use of sanctions. 
Again, the Austrian case is instructive for the significance of normative consensus. Partisan incentives might explain who was at the forefront of advocating sanctions, but they cannot explain why all other member states followed suit. Some governments were sceptical about the appropriateness and effectiveness of the proposed sanctions, but consented to the measures because of the strong normative salience of the values in reference to which they were framed as appropriate behaviour (Merlingen, et al., 2001, pp.62-5). Concerns about the effectiveness of Article 7 to restore democratic practices - after all, in Austria the sanctions in 2000 did increase the government's domestic support - mean that a normative commitment might not be incompatible with opposition to using Article 7, but from a constructivist perspective it could still explain support for it. The liberal democratic norms hypothesis therefore suggests that a member state government (EP party group) supports sanctions if it has a strong normative commitment to liberal democratic values.

Constructivism also draws attention to a second explanatory factor. Actors' attitudes towards sanctions might also depend on their general attitudes towards European integration. If actors' identities are incompatible with the idea of supranational governance, they are likely to reject the use of EU sanctions as illegitimate interference in domestic affairs. Thus, even if they had strong partisan incentives or a commitment to democratic norms, actors would only support sanctions if they consider European integration normatively appropriate. The supranational integration hypothesis therefore suggests that a member state government (EP party group) supports sanctions if it has a strong normative commitment to European integration. 
III. Analysis and findings: actor preferences towards the use of sanctions against democratic backsliding

Methodology

This article assesses these partly competing, partly complementary explanations through a fuzzy-set Qualitative Comparative Analysis (fsQCA) (Ragin, 2008; Schneider and Wagemann, 2012). The units of analysis, or cases, are key actors in the EU's decision to impose sanctions - member state governments and EP party groups - and their support or opposition to sanctions against Hungary or Romania. The outcome to be explained is these actors' position with regard to sanctions. The explanatory conditions are the actors' political orientation pertaining to the above hypotheses.

Expert surveys provide information about these political orientations of (government) parties in the member states (Bakker, et al., forthcoming) and EP political groups (McElroy and Benoit, 2012). With regard to partisan politics, actors' ideological distance from target government is assessed according to their general left/right orientation. Their normative commitment to supranational governance is expressed in their attitudes towards European integration. As a proxy for a party's commitment to liberal democracy, this article uses their 'ideological stance on democratic freedoms and rights'. Bakker et al. (forthcoming) describe the poles of this dimension in 
composite terms on a continuum from a green/alternative/libertarian (GAL) orientation to a traditional/authoritarian/nationalist (TAN) orientation. ${ }^{3}$

Unfortunately, data limitations prevent us from testing all four hypotheses systematically. Since no formal proposal to use Article 7 was submitted and voted on, we do not have comprehensive information on the positions of all member states. However, the EP voted on two resolutions that expressed serious concern about the new Hungarian constitution. These resolutions in combination with media reports (Agence Europe, 6.7.2011; 17.2.2012) allow us to infer the positions of the EP party groups: ALDE, Greens, S\&D, and United Left supported the possibility of sanctions, while EPP and ECR were against and EFP abstained. ${ }^{4}$ The systematic data for EP party groups can be complemented by less systematic data from media reports that suggest that among the member state governments, Belgium, the Netherlands, and Luxembourg $^{5}$ we attempting to mobilise support for sanctions (EUObserver, 16.2.2012). Moreover, we can increase the leverage of the analysis by including additional data about actors' preferences in the case of Romania, based on media reports. Leaders of EP party groups and governments who voiced their concerns and publicly considered the possibility of Article 7 if the problems persisted include the German government (Süddeutsche Zeitung, 12.7.2012) and the following party

\footnotetext{
${ }^{3}$ For further information on the relevant survey questions, calibration of the data for the analysis, and the detailed results of the fsQCA analysis, please see the Methodological Annex available on the author's personal webpage.

${ }^{4}$ On 5 July 2011, the EP adopted by 331 votes to 274 with 54 abstentions a resolution on the revised Hungarian constitution tabled by the S\&D, GUE/NGL, Greens/EFA and ALDE groups. On 16 February 2012 it adopted by 315 votes to 263 against with 49 abstentions a resolution on recent political developments in Hungary tabled by the same groups, after defeating two motions for a resolution tabled respectively by the EPP and ECR. Although there were no roll-call votes for either resolution, the records identify the groups that tabled them and those submitting counter-resolutions. ${ }^{5}$ Luxembourg is not covered in the survey by Bakker et al. (2012).
} 
groups: EPP (EUObserver, 6.7.2013), S\&D (Agence Europe, 11.7.2012), ALDE (Agence Europe, 19.7.2012), Greens (Agence Europe, 31.7.2012).

Adding data on Romania - where the Centre-left formed the government - allows us to make better inferences about the role of ideological distance. In the case of Hungary's centre-right government, actors with a TAN orientation also tended to be ideologically close (on a general left-right dimension) to the target government, which makes it difficult to distinguish whether their opposition to sanctions is due to ideological proximity or lack of a GAL orientation. The drawback of adding the less systematic data is that while it provides us with a fuller picture of actors who support sanctions, there is a possible bias in that actors supporting sanctions are overrepresented in our sample. While the findings about the impact of actors' political orientations on their attitudes towards sanctions should be generalisable beyond the cases analyzed, in the absence of more comprehensive data, we should interpret them with caution. Moreover, the lack of systematic data about member state governments means that we cannot assess the domestic partisan hypothesis - which is specific to national governments rather than transnational party groups. ${ }^{6}$ The following analysis thus assesses the remaining three hypotheses that apply equally to party groups and parties in government.

\footnotetext{
${ }^{6}$ Anecdotal support for this hypothesis could be that among the three governments alleged to garner support for sanctions against Hungary, two (the Netherlands and Belgium) face strong parties of the radical/populist right domestically.
} 
Table 1: $\quad$ Actor characteristics and support for Article 7 against Hungary and Romania

\begin{tabular}{|c|c|c|c|c|}
\hline $\begin{array}{l}\text { Actors (and target } \\
\text { government) }\end{array}$ & $\begin{array}{l}\text { Liberal } \\
\text { democracy } \\
\text { (GAL } \\
\text { orientation) }\end{array}$ & $\begin{array}{l}\text { Ideological } \\
\text { (left-right) } \\
\text { distance to } \\
\text { target } \\
\text { government }^{2}\end{array}$ & $\begin{array}{l}\text { Support for } \\
\text { European } \\
\text { integration }^{2}\end{array}$ & $\begin{array}{l}\text { Support (1) or } \\
\text { opposition (2) } \\
\text { to sanctions }\end{array}$ \\
\hline United Left (HU) & 15.1 & 10.86 & 6.1 & 1 \\
\hline Greens (HU) & 17.3 & 9.36 & 12.7 & 1 \\
\hline Greens (RO) & 17.3 & 1.6 & 12.7 & 1 \\
\hline S\&D (HU) & 14.7 & 5.96 & 12.6 & 1 \\
\hline S\&D (RO) & 14.7 & 1.8 & 12.6 & 1 \\
\hline ALDE (HU) & 15.8 & 1.86 & 13.9 & 1 \\
\hline ALDE (RO) & 15.8 & 5.9 & 13.9 & 1 \\
\hline EPP (HU) & 6.3 & 0.26 & 12.1 & 0 \\
\hline EPP (RO) & 6.3 & 7.5 & 12.1 & 1 \\
\hline ECR (HU) & 4.7 & 3.34 & 1.8 & 0 \\
\hline EFD (HU) & 3.6 & 4.84 & 0.1 & $0.4^{3}$ \\
\hline Netherlands (HU) & 8.52 & 0.69 & 12.31 & 1 \\
\hline Belgium (HU) & 11.07 & 4.34 & 17.87 & 1 \\
\hline Germany (RO) & 8.78 & 6.77 & 16.11 & 1 \\
\hline \multicolumn{5}{|c|}{$\begin{array}{l}\text { The letters in brackets indicate whether the target government is Hungary } \\
\text { (HU) or Romania (RO). }\end{array}$} \\
\hline $\begin{array}{l}\text { On a scale } f \\
\text { Abstention }\end{array}$ & m $0-20$ & & & \\
\hline
\end{tabular}

Analysis and findings: explanations of actor positions regarding the use of Article 7

Table 1 presents for each of the actors included in the analysis the raw data with regard to the three explanatory conditions (ideological distance to target governments; normative commitment to liberal democratic norms; normative commitment to supranational integration) and their support for sanctions in the case of Hungary and/or Romania. The fsQCA results in two equifinal solutions for the outcome 'support for sanctions' (parsimonious solution that makes simplifying assumptions about configurations of cases that the sample does not cover). Actors support sanction either if they are committed to the values of liberal democracy (i.e. have a GAL orientation) or if they are ideologically distant from the target government. Actors' 
attitudes towards European integration do not affect their support for sanctions. This result has both a very high consistency $(0.96)$ and coverage $(0.85)$. Conversely, the analysis produces one single explanation for the opposition to sanctions (identical results for the parsimonious, intermediate and complex solution): actors that are not strongly committed to liberal democracy (i.e. have a TAN orientation) oppose sanctions against target governments to which they are ideologically close (with regard to their left-right orientation). Although this solution has a high coverage (0.83), its consistency is fairly low (0.56). The outlier is the Dutch government (which supported sanctions against Hungary although it has a TAN orientation and is ideologically close), which decreases the consistency of the result considerably, given the small number of cases of explicit opposition to sanctions. However, if we analyze only the EP party groups with regard to Hungary - for which we have comprehensive data - then the consistency of this explanation for opposition to sanctions increases to 0.94 .

In other words, while (transnational) partisan politics do play a role in actors' decisions about whether to support the use of Article 7, this decision cannot be reduced to this factor. Instead, actors' normative commitment to liberal democracy appears to condition whether partisanship matters. Actors with a normative commitment to liberal democracy support sanctions against member states that breach democracy, irrespective of their partisan orientation. Partisan orientation only matters if an actor does not have a strong commitment to liberal democracy (i.e. has a TAN orientation): these actors will support sanctions against ideological rivals abroad and to oppose them if they target their partisan allies. 


\section{Alternative instruments against democratic backsliding and analytical framework for their effectiveness.}

Alternative instruments: social pressure, infringement procedures, and issue-linkage

Instead of using Article 7, the EU used (combinations of) three different measures in order to bring about changes in specific practices and legislation that infringed liberal democratic principles in Hungary and Romania. Social pressure is an instrument widely used by international institutions. It involves public criticism and shaming of non-compliant governments (see e.g. Johnston, 2001), and it can be preceded by less public efforts to persuade target governments of the normative appropriateness of compliance (see e.g. Checkel, 2001). EU institutions used social pressure towards both Hungary and Romania across the range of issues.

EU institutions can use the general infringement procedure of Articles 258 and 260 against non-compliance with a few specific values covered in Articles 2 and 7 TEU that also have their own legal basis in the treaty or secondary law - such as nondiscrimination (on grounds of gender, age, ethnic origin, etc). The Commission can launch infringement procedures autonomously and the ECJ can ultimately impose financial penalties against persistent non-compliance (see e.g. Börzel, 2001). In the case of Hungary, the Commission launched infringement procedures concerning three issues: the independence of the central bank, of the data protection authority, and the reduction of the retirement age of judges. 
Apart from the legal instruments explicitly intended to allow EU institutions to rectify infringements of liberal democratic principles, the EU might be able to use issue linkage to increase its leverage over non-compliant member states. EU institutions or member states can make more or less explicit links between non-compliance and the threat of withholding rewards for that member states in another issue area. The possibility of creating issue linkages depends on the issues and countries concerned. It is particularly strong if the member state in question has intensive preferences for an agreement in another policy area that requires unanimity between the member states. The potential for issue-linkage was particularly high in Romania. It was one of the few member states that had not yet been granted membership in the Schengen area, and was alongside Bulgaria the only country that was subject to post-accession monitoring through the Cooperation and Verification Mechanism (CVM) that regularly assesses progress in the fight against corruption, organized crime, and judicial reform. Some member states, including the Netherlands and Germany, have linked their approval of Schengen membership to progress with the CVM, although it is not a formal membership requirement. The Commission has linked breaches in the rule of law in Romania to continued CVM monitoring, and made negotiations on an IMF loan for Hungary dependent on restoring the independence of the central bank. The EU's initial suspension in March 2012 of 495 million Euros in structural funds for Hungary - as the first member state to be punished for failing to meet the budget deficit limits - was also seen as an attempt to increase the pressure on the Hungarian government.

Theoretical framework: the impact of the EU's instruments in Hungary and Romania 
The article distinguishes between two mechanisms to explain (variation in) the effectiveness of the EU's attempts to bring about domestic changes that redress breaches of democracy in member states. Rationalist institutionalism focuses on target actors' susceptibility to material incentives. The key instruments that rely on this mechanism are infringement procedures and issue-linkage, which both entail the threat of material sanctions. According to this explanation, the EU's ability to bring about domestic change depends primarily on the target government's vulnerability to the threatened sanctions and the costliness of the changes demanded by EU institutions. Thus, according to a material leverage hypothesis, target governments carry out the domestic changes demanded by the EU if the costs of threatened EU sanctions exceed the domestic adjustment costs.

Constructivism focuses on social pressure as the key mechanism leading to domestic change. Target governments change undemocratic rules and practices either because the EU persuades them that this constitutes appropriate behaviour for community members, or if they are susceptible to social sanctions. Factors that affect target governments' perceptions of legitimacy and susceptibility to shaming relate both to the EU's practice and to the characteristics of their target (see e.g. Checkel, 2001; Epstein, 2008; Johnston, 2001). Social pressure is more likely to succeed if the government leader is a 'novice' in international relations; and if she has a positive normative attachment to the EU. The perceived legitimacy of the EU's demands is higher if they follow general standards of procedural legitimacy; if the demands are initially conveyed in a process of non-hierarchical arguing about appropriate standards; if they are externally validated through an independent institution (e.g. the Council of Europe's Venice Commission); and if there is internal consensus about the 
demands. The social pressure hypothesis suggests that target governments carry out the domestic changes demanded by the EU if they perceive these demands as legitimate.

\section{Analysis and findings: effectiveness of EU instruments against democratic backsliding in Hungary and Romania}

In Hungary, the EU's attempts to stem democratic backsliding focused in particular on the independence of the media, of the data protection authority, and of the central bank, as well as on the retirement age of judges. For Romania, the Commission prepared an 11-point list of demands that centred on the validity requirements for the referendum to impeach President Băsescu, as well as the independence of the judiciary and the fight against corruption.

The explanatory factors for the effectiveness of the EU's attempts varied across issues and countries, with regard to both the EU's ability to threaten material sanctions (and the magnitude of its material leverage) and the conditions for the use of social pressure. The domestic conditions for social pressure were much more favourable in Romania than in Hungary. The 39-year old Ponta was a relative 'novice' to political leadership and international relations while Orban had a longstanding history as party leader and previous PM. Attitudes towards the EU are generally much more positive in Romania than they are in Hungary, and among Fidesz voters in particular. While there is a general desire to be recognized as 'good Europeans' among Romanian elites and public, Orban regularly used scathing criticism of the EU to shore up domestic 
support. ${ }^{7}$ Finally, for the Romanian government, relinquishing undemocratic practices that removed constraints on the exercise of power was strategically costly, but did not affect normative beliefs. By contrast, Orban held a deep normative commitment to the goals underpinning his government's hold on power, reflected in framing the constitutional changes as the final steps in his long struggle to overcome communism in Hungary.

Table 2: Overview of EU instruments and outcomes

\begin{tabular}{|c|c|c|c|}
\hline Country & Issue & $\begin{array}{l}\text { Instruments \& leverage } \\
\text { (in addition to social } \\
\text { pressure) }\end{array}$ & $\begin{array}{l}\text { Outcome (compliance } \\
\text { with EU demands) }\end{array}$ \\
\hline \multirow[t]{4}{*}{ Hungary } & Media law & (Social pressure only) & Minor compliance \\
\hline & Central Bank independence & $\begin{array}{l}\text { Infringement procedure } \\
\text { (threat of ECJ fines); } \\
\text { issue-linkage (IMF loan) }\end{array}$ & Compliance \\
\hline & $\begin{array}{l}\text { Independence of the Data } \\
\text { Protection Authority }\end{array}$ & $\begin{array}{l}\text { Infringement procedure } \\
\text { (threat of ECJ fines) }\end{array}$ & Incremental compliance \\
\hline & Retirement age of judges & As above & Incremental compliance \\
\hline \multirow[t]{3}{*}{ Romania } & Independency of judiciary & $\begin{array}{l}\text { Issue linkage: CVM (rule } \\
\text { of law), Schengen } \\
\text { membership }\end{array}$ & Compliance \\
\hline & $\begin{array}{l}\text { Quorum and validation of } \\
\text { impeachment referendum }\end{array}$ & As above & Compliance \\
\hline & Corruption control & As above & Partial compliance \\
\hline
\end{tabular}

\footnotetext{
${ }^{7}$ For example, 'Hungarians will not live as foreigners dictate, will not give up their independence or their freedom, therefore they will not give up their constitution either' (Guardian 16.3.2012).
} 
Table 2 (above) presents an overview of the variation across different issues in the material leverage that the EU used (in addition to social pressure) and the outcomes with regard to the target government's compliance with the EU's demands.

Hungary: Media law; retirement age of judges; independence of the Data Protection Authority, and of the Central Bank in Hungary

The Hungarian Media law, adopted in 2011, was heavily criticized by a number of member states, EP party groups and the Commission (Süddeutsche Zeitung, 29.12.2010; 2.1.2012). Among other contentious elements, it established a new Media Council - whose five members on a 9-year term only include Fidesz supporters. It is in charge of licensing and tendering, the appointment of directors of public outlets, and can impose high fines on media outlets whose coverage is judged not to be 'politically balanced', raising concerns about self-censorship. Although the Commission made the debateable claim that the media law breached the EU media directive, it decided not to use infringement procedures (Agence Europe, 18.1.2012). Instead, Commissioner Neelie Kroes was satisfied that the Commission's concerns had been addressed in an exchange of letters with the Hungarian government, which promised to ease rules for foreign media and to soften the rules against 'unbalanced' coverage and 'offensive' internet content (Süddeutsche Zeitung, 7.3.2011; EUObserver, 17.1.2012).

After the Hungarian Constitutional Court declared some elements of the media law unconstitutional, the controversy reignited when the Media Council withdrew the frequency for Klubradio, the main independent radio channel in the country, leading 
to criticism from the Commission, although there was no EU law that allowed it to act (Agence Europe, 18.1.2012). A Budapest court granted a temporary relief for Klubradio to stay on air (European Voice, 27.3.2012), but according to a Council of Europe expertise on the Hungarian Media law, the government's changes still do not meet European human rights standards. Freedom of the press remains problematic since the Media Council 'still controls the entire broadcast sector and has ... [the] legal power to reregulate print and online media (Bánkuti, et al., 2012).' In sum, the EU's use of social pressure to achieve greater plurality and independence of the media was largely ineffective.

In January 2012, the Commission started infringement procedures against Hungarian legislation in three issue areas that had a separate basis in EU law. The lowering of the retirement age of judges from 70 to 62 (used to replace a generation of judges with new party-loyal judges) infringed Directive 2000/78/EC on equal treatment in employment. Measures to restrict the independence of the national data protection supervisory authority and of the Hungarian Central Bank respectively breached Article 16 TFEU and Directive 95/46/EC on data protection and Article 130 TFEU. Moreover, concerning the independence of the Central Bank, the EU did not only use the infringement procedures - with the threat of financial penalties by the ECJ - but additionally used issue linkage. In December 2011, the EU and the IMF both made negotiations on 15-20 billion Euros in financial assistance dependent on restoring the independence of the Central Bank (Agence Europe, 4.1.2012). In April 2012, the Commission declared itself satisfied with the changes to the Central Bank's legal status, but not in the other two cases and referred Hungary to the ECJ. These cases continued in early 2013, although the Hungarian government had agreed to comply 
with the ECJ judgements establishing infringements (Süddeutsche Zeitung, 30.1.2013).

Romania: independence of the judiciary, of the anti-corruption institutions and quorum requirements for the referendum to impeach the president

In contrast to the Hungarian case, the EU moved fairly quickly after the Romanian government had impeached president Băsescu and took measures limiting the powers of the constitutional court to scrutinize its attempt to change the 50 percent participation quorum in the referendum required to confirm the impeachment. Commission President Barroso and Council President Van Rompuy both arranged a meeting with Ponta in Brussels on 12 July 2012. Barroso obtained a commitment from Ponta to comply with a list of 11 measures that the Commission deemed necessary to restore the rule of law (Agence Europe, 14.7.2012).

These measures broadly address three issues. First, measures to respect the independency of judiciary, including compliance with constitutional court decisions; reinstatement of powers of the court; and to refrain from using emergency ordinances, publishing judicial decisions selectively in the Official Journal, and criticising judicial decisions and intimidating judges. The second main issue was respecting the 50 percent turnout requirement to validate the impeachment referendum. The third set of measures centred on the issue of corruption control, including the independence of the Ombudsman, Prosecutor, and anti-corruption agency; resignation of ministers and MPs convicted of corruption; and the non-use of interim presidential pardons. 
Ponta quickly declared his willingness to comply with the demands, and eventually recognized that the referendum to impeach the president had failed - despite overwhelming approval by 97 percent of voters - since the turnout was only 46 percent, largely due to the opposition's strategy of boycotting the referendum (Agence Europe, 31.7.2012). At the same time, despite the broad compliance by the Ponta government with the EU's demands, the CVM report of 30 January 2013 criticized remaining shortcomings with corruption control, especially that individuals under investigation for corruption took office as ministers and MPs after the government's overwhelming victory in the December 2012 election (EUObserver, 30.1.2012).

The EU's influence in the Romanian case relied heavily on social pressure, although it was carried out in the shadow of explicit and implicit issue linkage. The political crisis in Romania coincided with the scheduled publication of the CVM report on Romania on 18 July. Although CVM does not usually cover an assessment of the rule of law, the Commission focused strongly on the concerns that the crisis raised for the functioning of democracy and the rule of law. It concluded that further monitoring through the CVM was necessary. However, a further - although much less explicit issue linkage concerned Romania's aspiration to Schengen membership. Although the Commission had stated repeatedly that both Romania and Bulgaria met the conditions for membership, initially the Dutch and Finnish governments indicated that they would block an agreement until the two countries had demonstrated more progress with the issues covered by the CVM - corruption control, reform of the judiciary and the fight against organized crime - although the CVM did not envisage such a link to Schengen accession. Following the Romanian crisis, the German and French governments also stated their intention to link these issues. 
Findings: conditions for the effectiveness of EU pressure

A comparison of the outcomes of the EU's attempts to bring about changes in domestic practices shows that the main variation in the EU's success is across countries. The EU's influence was generally effective in Romania, but much less so in Hungary where the EU anyway addressed the breaches of liberal democracy only highly selectively. But there is also some intra-country variation across issues. In Hungary, the EU had much less influence on the media law than the three issues that were subject to infringement procedures, and among the latter, compliance was much faster regarding Central Bank independence than the other two issues. In Romania, despite generally good compliance, shortcomings remained with regard to the EU's demands for corruption control.

How can we explain these patterns and what do they tell us about the relative importance of material leverage and social pressure? The cross-issue variation within countries supports the material leverage hypothesis. In Hungary, the EU's influence was weakest on the issue where it only used social pressure, while compliance was fastest on the issue where the EU could use issue linkage to IMF aid in addition to its infringement procedure. In Romania, the more problematic compliance with regard to corruption control arguably concerns the issue in which the costs of compliance with the EU's demands are highest.

Unfortunately, in the cross-country variation, the EU's greater influence in Romania is overdetermined. Conditions in Romania were much more conducive to the effective 
use of social pressure, but at the same time, the EU's potential material leverage was also much greater through the possible issue-linkage to Schengen membership. In the absence of clearer evidence to assess the respective causal impact of social pressure and issue-linkage in Romania, a cautious interpretation of the outcome is that EU pressure can be effective even without Article 7, but only if the conditions for both social pressure and material sanctions are favourable. These are demanding conditions.

However, even if the currently available evidence does not allow us to decide whether both mechanisms were necessary, or whether either would have been by itself sufficient, counterfactual reasoning might give reason for optimism that under favourable conditions for social pressure, material leverage might not be necessary. For Romania, issue-linkage was only explicitly established to CVM. But CVM is a social sanction; it operates through the stigma attached to continued monitoring and scrutiny. Negative CVM reports do not entail significant material sanctions, only the non-recognition of national court decisions in other member states. The link to Schengen membership suggested by some member states was repeatedly denounced by the Commission as illegitimate, although the unanimity requirement still made it a real threat. However, this link predated the Romanian crisis of 2012, yet it had still not led to the necessary reforms in either Romania or Bulgaria. It is therefore debateable whether the threat of withholding Schengen membership motivated the Romanian government to change undemocratic practices since such compliance by itself did not guarantee Schengen membership, which still required separate progress with corruption control that the Romanian government had been unable to deliver. Thus while the cautious interpretation is that the EU can only effectively counteract 
democratic backsliding without Article 7 if very demanding conditions for both social and material sanctions are present, there is reason for cautious optimism that favourable conditions for social pressure might be sufficient.

\section{Conclusions}

Can EU membership lock-in democracy in post-authoritarian states? Can the EU remedy democratic backsliding after accession? This article has analyzed the cases of Hungary and Romania in 2012/13 to answer these broader questions. These cases raise two key questions: how can we explain that the EU did not use its most powerful sanction mechanism against breaches of liberal democracy, namely Article 7? And why were alternative instruments generally more successful in Romania than Hungary, as well as more effective on some issues than others?

Available data on the positions of EP party groups and member state governments towards using Article 7 against Hungary or Romania suggests that a combination of partisan politics and weak normative consensus is an important constraint on the use of this sanctioning mechanism. Actors with a weaker normative commitment to liberal democracy (expressed in a traditional/authoritarian/nationalist orientation) appear reluctant to sanction governments formed by their partisan allies (i.e. who are ideologically close on the left-right dimension). Conversely, actors normatively committed to liberal democratic principles (reflected in a green/alternative/libertarian orientation) support sanctions irrespective of the target government's ideological orientation, while those with a TAN orientation support them (only) against their ideological rivals abroad. If we can generalize from our sample, then an agreement on 
sanctions need not require that the Council is exclusively composed of governments with a GAL orientation, depending on the partisan orientation of the target government. Since a GAL orientation is generally more likely among parties on the left of the general left-right dimension, this might imply that democratic backsliding is more likely to be punished in countries that are governed by parties of the left rather than the right.

Despite the EU's inability to mobilize its strongest instrument, EU institutions had some success in pressing for changes in undemocratic practices. Especially in the case of Romania, PM Ponta largely complied with EU demands. In Hungary, the EU's influence was generally much more limited. Its failure to use Article 7 left the broader underlying problems unchallenged and only addressed selected issues in isolation (see also Jenne and Mudde, 2012, p.150). On such issues, however, the EU achieved some incremental changes.

The intra-country cross-issue variation of the EU's influence supports the claim that variation in the EU's material leverage affects its ability to elicit compliance with its demands. Especially when the conditions for social pressure were unfavourable - as in Hungary - social pressure alone was largely ineffective, while the threat of fines by the ECJ led to compliance, particularly if it was combined through issue linkage with the threat of withholding other benefits (i.e. the IMF loan). The main exceptions to Romania's compliance with EU demands concerned corruption control. These were arguably the most costly and a key motivation to remove checks on the government's autonomy in the first place. This cross-issue variation confirms the expectation of the material leverage hypothesis that the EU's influence depends both on the size of the 
material sanctions that it can threaten and the size of the domestic costs of compliance. This finding underscores concerns about the EU's ability to redress illiberal practices in its membership given the difficulties to agree on the use of Article 7, the limited extent to which liberal democratic principles also have a separate legal basis that allows the use of EU infringement procedures, and the fact that many possibilities of issue-linkage that the Romanian and Hungarian cases offered-with regard to Schengen membership, an IMF loan, or the possible withholding of regional funds due to excessive deficits - do not generally apply to all EU member states.

We have insufficient empirical evidence to assess in the Romanian case the respective causal impact of the favourable conditions for social pressure and of the material leverage through the implicit possibility of denying Schengen membership. A cautious interpretation therefore suggests that the EU might only be able to rectify post-accession backsliding under a very demanding constellation of conditions that allow it to apply both social and material pressure. This interpretation would lead us to a rather pessimistic assessment of the EU's ability to counteract democratic backsliding in its members, not least since the scope for issue-linkage is much more limited with regard to most other member states that are already members of Schengen. However, since Romania's accession to Schengen remains independently blocked by some member states due to the limited progress with corruption control, fight against organized crime and reform of the judiciary, a more optimistic interpretation suggests that under favourable conditions for social pressure, material leverage might be unnecessary. This interpretation implies that the EU might still have some hope of reversing democratic backsliding when faced with a pro-EU 
leadership with illiberal tendencies, but conversely, the EU's influence on Eurosceptic illiberal leaders might be especially limited.

\section{References}

Bakker, R., de Vries, C., Edwards, E., Hooghe, L., Jolly, S., Marks, G., Polk, J., Rovny, J., Steenbergen, M. and Vachudova, M. (forthcoming) 'Measuring Party Positions in Europe: The Chapel Hill Expert Survey Trend File, 1999-2010'. Party Politics.

Bánkuti, M., Halmai, G. and Scheppele, K.L. (2012) 'Disabling the Constitution'. Journal of Democracy, Vol. 23, No. 3, pp. 138-46.

Börzel, T.A. (2001) 'Non-Compliance in the European Union: Pathology or Statistical Artefact?' Journal of European Public Policy, Vol. 8, No. 5, pp. 803-24.

Checkel, J.T. (2001) 'Why Comply? Social Learning and European Identity Change'. International Organization, Vol. 55, No. 3, pp. 553-88.

Epstein, R.A. (2008) 'The Social Context in Conditionality: Internationalizing Finance in Postcommunist Europe'. Journal of European Public Policy, Vol. 15, No. 6, pp. 880-98.

Epstein, R.A. and Sedelmeier, U. (2008) 'Beyond Conditionality: International Institutions in Postcommunist Europe after Enlargement'. Journal of European Public Policy, Vol. 15, No. 6, pp. 795-805.

Jenne, E.K. and Mudde, C. (2012) 'Can Outsiders Help?' Journal of Democracy, Vol. 23, No. 3, pp. 147-55.

Johnston, A.I. (2001) 'Treating International Institutions as Social Environments'. International Studies Quarterly, Vol. 45, No. 4, pp. 487-515.

Levitz, P. and Pop-Eleches, G. (2010) 'Why No Backsliding? The European Union's Impact on Democracy and Governance before and after Accession'. Comparative Political Studies, Vol. 43, No. 4, pp. 457-85.

McElroy, G. and Benoit, K. (2012) 'Policy Positioning in the European Parliament'. European Union Politics, Vol. 13, No. 1, pp. 150-67. 
Merlingen, M., Mudde, C. and Sedelmeier, U. (2001) 'The Right and the Righteous? European Norms, Domestic Politics and the Sanctions against Austria'. Journal of Common Market Studies, Vol. 39, No. 1, pp. 59-77.

Moravcsik, A. (2000) 'The Origins of Human Rights Regimes: Democratic Delegation in Postwar Europe'. International Organization, Vol. 54, No. 2, pp. 217-52.

Pop-Eleches, G. (2013) 'Learning from Mistakes: Romanian Democracy and the Hungarian Precedent'. Newsletter of the European Politics and Society Section of the American Political Science Association, Vol. Winter 2013, pp. 9-12.

Pridham, G. (2008) 'The EU's Political Conditionality and Post-Accession Tendencies: Comparisons from Slovakia and Latvia'. Journal of Common Market Studies, Vol. 46, No. 2, pp. 365-87.

Ragin, C.C. (2008) Redesigning Social Inquiry: Fuzzy Sets and Beyond (Chicago: University of Chicago Press).

Sadurski, W. (2012) Constitutionalism and the Enlargement of Europe (Oxford: Oxford University Press).

Scheppele, K.L. (2013) 'Not Your Father's Authoritarianism: The Creation of the "Frankenstate"'. Newsletter of the European Politics and Society Section of the American Political Science Association, Vol. Winter 2013, pp. 5-9.

Schimmelfennig, F. (2005) 'Strategic Calculation and International Socialization: Membership Incentives, Party Constellations, and Sustained Compliance in Central and Eastern Europe'. International Organization, Vol. 59, No. 4, pp. 827-60.

Schimmelfennig, F. and Sedelmeier, U. (2004) 'Governance by Conditionality: EU Rule Transfer to the Candidate Countries of Central and Eastern Europe'. Journal of European Public Policy, Vol. 11, No. 4, pp. 661-79.

Schneider, C.Q. and Wagemann, C. (2012) Set-Theoretic Methods for the Social Sciences: A Guide to Qualitative Comparative Analysis (Cambridge: Cambridge University Press).

Sedelmeier, U. (2008) 'After Conditionality: Post-Accession Compliance with EU Law in East Central Europe'. Journal of European Public Policy, Vol. 15, No. 6, pp. 806-25. 
Sedelmeier, U. (2012) 'Is Europeanisation through Conditionality Sustainable? Lockin of Institutional Change after EU Accession'. West European Politics, Vol. 35, No. 1, pp. 20-38.

Spendzharova, A.B. and Vachudova, M.A. (2012) 'Catching Up? Consolidating Liberal Democracy in Bulgaria and Romania after EU Accession'. West European Politics, Vol. 35, No. 1, pp. 39-58.

Vachudova, M.A. (2005) Europe Undivided: Democracy, Leverage and Integration after Communism (Oxford: Oxford University Press).

Wallace, W. (1996) Opening the Door: The Enlargement of NATO and the European Union (London: Centre for European Reform). 